${ }^{1}$ Yudkin, J., Lancet, i, 1335 (1963).

${ }^{2}$ Zlatkis, A., Zak, B., and Boyle, G. J., J. Lab. Clin. Med., 41, 486 (1953).

${ }^{3}$ King, E. J., and Allott, E. N., Recent Advances in Clinical Pathology, second ed. (edit. by Dykes, S.,C.), 271 (Churchill, London, 1962).

4 Stern, I. S., and Shapiro, B., J. Clin. Pathol., 6, 158 (1953).

"Albrink, M. J., J. Lipid Res., 1, 53 (1959).

' Hellem, A. J., J. Clin. Lab. Invest., 12, Suppl. 51 (1960).

${ }^{7}$ Beveridge, J. M. R., Connell, W. F., Mayer, G. A., and Haust, H. L., J. $61(1960)$

${ }^{8}$ Qureshi, R. U., and Salter, A., Nature, 212, 789 (1966).

'Hodges, R. E., and Krehl, W. A., Amer. J. Clin. Nutrit., 5, 334 (1965).

${ }^{10}$ Kuo, P. T., and Bassett, D. R., Ann. Intern. Med., 62, 1199 (1965).

"Macdonald, I., and Braithwaite, D. M., Clin. Sci., 27, 23 (1964).

${ }^{12}$ Kuo, P. T., Feng, L., Cohen, N. N., Fitts, W. T., and Miller, L. D., Amer. $20,116(1967)$.

i3 Rif kind, B. M., Lawson, D. H., and Gale, M., Lancet, ii, 4778 (1966).

is Nutrit. Rev., 25, 172 (1966).

${ }^{15}$ Aitken, J., Robinson, D., and Yudkin, J., Proc. Nutrit. Soc., 26, xxx (1967).

16 Finney, D. J., Biometrika, 35, 149 (1948).

17 Mann, H. B., and Whitney, D. R., Ann. Math. Statist., 18, 50 (1947).

${ }^{18}$ Wilcoxon, F., Some Rapid Approximate Statistical Procedures (Amer. (yanamid Co., New York, 1949).

\section{Chemosterilization of Schistosoma mansoni}

THE range of chemical agents which can produce sterility in experimental male rodents is gradually increasing. (For recent surveys, see Jackson ${ }^{1,2}$.) The list includes nitroaromatic compounds, for example, nitrofuranes, nitrothiazoles and nitropyrroles, besides a variety of compounds of the alkylating category. Recently, a nitrothiazole derivative, niridazole ('Ambilhar'), has been introduced for the treatment of schistosomiasis ${ }^{3,4}$ and part of its effective toxic action involves damage to the gonads of the male and female parasite. Reversible inhibition of spermatogenesis in mice by this compound has been described $^{5}$. Here we wish briefly to record the ability of two simple unrelated substances, ethylenedimethanesulphonate (EDS) and hexamethylphosphoramide (HMPA) effectively to inhibit the reproductive capacity of Schistosoma mansoni within the mouse.

Both compounds were administered daily by gavage to female albino mice (originally an $S P F$ Swiss strain, obtained from ICI (Pharmaceuticals), Ltd, Alderley Park, Cheshire). Dosing began 1 week after exposure to infection by approximately 100 cercariae. Treatment with EDS continued for 5 weeks at a level of $200 \mathrm{mg} / \mathrm{kg}$ in 40 per cent dimethylsulphoxide-water and with HMPA for 7 weeks at $250 \mathrm{mg} / \mathrm{kg}$ in water. Bi-weekly tests for miracidia begun 8 weeks after infection were completely negative in both series and remained so for 2 months. Parallel controls yielded consistent evidence of infection with counts as high as 200 miracidia per four mice even. in the later weeks of the experiments. After death, schistosomes were present in mice of both treated and control series in comparable numbers. The sterile parasites did not differ notably from the controls except that the gonads, particularly in the females, were small, while the vitelline glands in the latter appeared atrophic. Male mice given a comparable course of EDS were sterile in the second week of treatment and probably remained permanently so.

A 2 week course of oral EDS at $200 \mathrm{mg} / \mathrm{kg}$ daily, begun 10 weeks from the initial infection with cercariae, eliminated miracidia within 2 weeks although recovery occurred later; $100 \mathrm{mg} / \mathrm{kg}$ intraperitoneally was similarly effective. The phosphoramide $(250 \mathrm{mg} / \mathrm{kg}$ ) was ineffective in similar experimental conditions. It should be noted that the mouse is particularly tolerant to the relatively high doses used in these experiments, especially to the sulphonic ester. As in rodents treated with EDS and HMPA, sexual activity of sterile males seemed unaffected because schistosomes were found to be in copulo in the mesenteric and portal blood vessels, as in the control series.
EDS belongs to a homologous series of diol diesters of methanesulphonic acid which includes the antileukaemic drug busulphan ('Myleran'). In general, these compounds exert inhibitory effects on the spermatogenic cells of rodents ${ }^{2,6}$ and also on granulocyte precursor cells of bone marrow ${ }^{6-8}$. EDS although antispermatogenic, however, is exceptional in that it does not produce suppressive effects against haemopoietic cells in either rat or mouse. Its ability to sterilize male schistosomes was rather unexpected because sulphonic esters have not found favour as chemosterilants against insect species ${ }^{9}$. The antifertility and antispermatogenic actions of HMPA in rodents were briefly reported in 1966 (ref. 10). In our experience, neither compound has interfered with the reproductive capacity of the female rodent, so that an effect on the female schistosome was not anticipated. The nitrothiazole derivative niridazole was reported to damage the gonads of both sexes; indeed, a predominant action on the female was suggested ${ }^{11}$. It is possible that the effects on the female parasite may occur secondarily to a sterile male partner.

This work is supported by grants from the Ford Foundation and Wellcome Trust and was carried out with the assistance of a Medical Research Council training scholarship (P. D.). We thank Professor R. Peters, School of Tropical Medicine, Liverpool, for providing facilities to infect the mice used.

\section{HAROLD JACKSON \\ Pamela Davies MARION BOCK}

Unit of Reproductive Pharmacology, University of Manchester.

Received March 21, 1968.

${ }^{1}$ Jackson, H., Prog. in Drug Research, 7, 134 (1964).

2 Jackson, H., Antifertility Compounds in the Male and Female, pp. 214 (American Lecture Series) (C. C. Thomas, Springfield, Illinois, 1966).

${ }^{3}$ Schulert, A. R., Browne, H. G., and Salem, H. H., Trans. Roy. Soc. Trop. Med. Hyg., 58, 48 (1964).

4 Lambert, C. R., Ann. Trop. Med. Parasitol., 58, 292 (1964).

${ }^{5}$ Lambert, C. R., Sinari, V. S. P., and Tripod, J., Acta Tropica, 22, 155 (1965).

- Jackson, H., Brit. Med. Bull.,20, 107 (1964).

${ }^{7}$ Fox, B. W., Nature,212, 1058 (1966).

8 James, R. M. V., Brit. J. Haematol., 12, 546 (1966).

Borkovec, A. B., Adv. in Pest Control Research, 7, 1 (1966).

${ }^{10}$ Jackson, H., and Craig, A. W., Nature, 212, 86 (1966).

${ }^{11}$ Striebel, H. P., and Kradolfer, F., Acta Tropica, Suppl. 9, 54 (1966).

\section{Leukoegresin: a Factor from Rabbit Skin associated with Leucocytic Emigration in the Arthus Reaction}

INCREASED vascular permeability and leucocyte emigration are important events in inflammation. In the Arthus reaction the time course of these events is distinctive, suggesting a chemical mediator different from those in other forms of inflammation ${ }^{1}$. We isolated permeability factors from the Arthus skin lesion during the period of increased vascular permeability change and then purified them ${ }^{2-5}$. Promoters of leucocyte emigration have been found in leucocytes or tissue-serum mixtures ${ }^{6,7}$ and lymph node cells ${ }^{8}$, but these substances have not yet been purified satisfactorily. The cationic protein from polymorphonuclear (PMN) lysosomes ${ }^{9,10}$ and leucotaxine ${ }^{11}$ from pleural exudates stimulate PMN emigration, but they also increase vascular permeability. This communication deals with isolation and purification of a factor which is associated with leucocyte emigration in Arthus lesions.

Arthus reactions were induced simultaneously in ten sites on an area measuring $15 \times 12 \mathrm{~cm}$ on the clipped flanks of $2-2.3 \mathrm{~kg}$ rabbits sensitized with bovine serum albumin ${ }^{2}$. The increase in vascular permeability reached its peak in about $4.5 \mathrm{~h}^{2}$, leucocyte emigration in about $12 \mathrm{~h}^{1}$. The skin bearing the lesions was excised, extracted 